\title{
Scientific look at cold fusion inconclusive
}

\section{- International meetings produce interest - Laboratories struggle to replicate findings}

\section{Dallas}

THE tantalizing prospect of 'cold fusion' continued to galvanize interest around the world last week with two international conferences making the first public professional assessment of the results while daily newspaper stories continued to describe rumours, reports and retractions of cold-fusion experiments.

In Dallas, a 10,000 seat basketball arena was filled to near capacity on Wednesday as chemists attending the national meeting of the American Chemical Society (ACS) gathered to hear the latest results of experiments by Stanley Pons of the University of Utah. At the same time in Erice, Italy, a smaller gathering made up predominantly of physicists witnessed the first confrontation between Martin Fleischmann, Pons's colleague, and Brigham Young University's Steven Jones, who has also performed cold-fusion experiments. The two universities have been competing for primacy in the cold-fusion arena.

Since the University of Utah announced its results at a press conference on 23 March, laboratories all over the world have been trying to replicate the relatively simple experiments. Pons and Fleischmann use palladium and platinum electrodes in a lithium electrolyte solution of deuterated water. When a current is applied to the cell, deuterium is taken up by the palladium cathode, and, according to the University of Utah team, can fuse, releasing energy. So far, no one has reported unequivocal confirmation of the Fleischmann/Pons results.

But that did not dissuade some 7,000 chemists, as well as a gaggle of journalists and members of the public, from sitting in rapt attention as Pons described his experiments. ACS decided at the last minute to hold a special forum on cold fusion, but society officials were quick to point out that the decision did not constitute any validation of the experimental results.

At Dallas, chemists welcomed the prospect that cold fusion might represent a victory for chemistry over physics. Opening the special session, ACS presi-

\section{Erratum}

A news item in the 13 April issue of Nature (338, 529; 1989) incorrectly referred to Brigham Young University researcher Steven Jones as Robert Jones. The same article also cited the publication date for an article in the Journal of Electroanalytical Chemistry and Interfacial Electrochemistry by Stanley Pons and Martin Fleischmann as 10 March. The correct date is 10 April. dent Clayton Callis said the goal of fusion as an energy source has remained elusive, and that physicists's efforts at hot fusion using tokamaks and lasers were "apparently too expensive and too ambitious to lead to practical power". To applause from the crowd, he added, "Now it appears that chemists have come to the rescue".

In his speech, Pons joked about the high cost of physicists' attempts at fusion by calling his own apparatus the "U-1 Utah tokamak". A picture showed a glass electrochemical cell inside a cooling bath made from an ordinary rubber kitchen bucket.

But Harold Furth, director of the Princeton University Plasma Physics Laboratory, raised serious questions about the conclusion that Pons was seeing fusion. Furth said that the experimenters would have to show that the same reaction did not occur with light water rather than deuterated water before nuclear physicists would try to explain why the deuterium was fusing inside the palladium lattice.

Scepticism for fusion as the explanation for the heat seen by the University of Utah team was also expressed at the Erice meeting (see page 616).

At a meeting between Fleischmann, Jones and Pons as well as the presidents of BYU and the University of Utah on 6 March, both teams agreed to submit on 24 March papers describing their results to Nature. But when the University of Utah team held a press conference on 23 March, the BYU team submitted their work to Nature the same day.

Now both universities are working to prove that their people were the first to show that relatively high rates of fusion could occur in an electrochemical cell The Pons/Fleischmann results have been far more dramatic than those reported by
Jones, with claims that the electrochemical cell produces a large excess of heat. Jones's paper will appear in the next issue of Nature.

At the Italian meeting, Jones and Fleischmann were cordial towards one another, and press photographers eagerly snapped pictures of the two smiling for the cameras.

Daily newspapers and television programmes continue to be a favoured forum for reporting new scientific results. On 10 March, Texas A \& $\mathrm{M}$ researchers held a press conference to say that they were seeing between 60 and 80 per cent excess heat production using an electrochemical cell similar to the one at the University of Utah. On the same day, Georgia Institute of Technology scientists held a press conference to say that they had produced neutrons and tritium from a similar experimental apparatus, but by the end of the week they had to retract that claim. citing problems with the instruments used to detect the neutrons.

On Wednesday, 12 March, reports surfaced in the Western media that the University of Moscow had successfully replicated the experiment, but no details have been forthcoming (see page 607). The same day, rumours circulated that Massachusetts Institute of Technology (MIT) professor Peter Hagelstein had submitted four theoretical papers explaining how fusion could occur without generating a lethal amount of ra ioactivity.

MIT has subsequently released a summary of the papers and filed a patent application dealing with their possible technical application. MIT also announced that another MIT professor. Keith Jones, had a theory that explained the Utah results without resorting to a new theory of nuclear fusion.

Although there is uncertainty about the University of Utah results even among those inclined to believe them, financial support for the work has grown. The Office of Naval Research (ONR) has awarded the University of Utah team an additional grant of some $\$ 400,000$ over the next 32 months for work on cold fusion. nearly doubling ONR support for Pons' laboratory.

\section{IMAGE UNAVAILABLE FOR COPYRIGHT REASONS}

